\title{
Thermal sensitivity of cell metabolism of different Antarctic fish species mirrors organism temperature tolerance
}

\author{
Gisela Lannig $^{1}\left[\right.$ - Anette Tillmann ${ }^{1} \cdot$ Sarah Howald ${ }^{1} \cdot$ Laura S. Stapp $^{2}$
}

Received: 11 December 2019 / Revised: 14 September 2020 / Accepted: 16 September 2020 / Published online: 30 September 2020

(c) The Author(s) 2020

\begin{abstract}
Despite cold adaptation, Antarctic fish show lower growth than expected from the van't Hoff's $\mathrm{Q}_{10}$ rule. Protein synthesis is one of the main energy-consuming processes, which is downregulated under energy deficiency. Considering the effect of temperature on growth performance, we tested if temperature-dependent cellular energy allocation to protein synthesis correlates with temperature-dependent whole-animal growth and thus thermal tolerance. Cell respiration and energy expenditure for protein synthesis were determined in hepatocytes of the circumpolar-distributed Antarctic eelpout Pachycara brachycephalum after warm acclimation $\left(0^{\circ} \mathrm{C}\right.$ vs $\left.5{ }^{\circ} \mathrm{C}\right)$ and, of two notothenioids the sub-Antarctic Lepidonotothen squamifrons and the high-Antarctic icefish Chionodraco hamatus. We used intermittent-flow respirometry to analyse cellular response to acute warming from 5 to $10^{\circ} \mathrm{C}(P$. brachycephalum $)$ and from 1 to $5{ }^{\circ} \mathrm{C}($ L squamifrons, C. hamatus $)$. Warming-induced rise in respiration was similar between 0 - and $5^{\circ} \mathrm{C}$-acclimated $P$. brachycephalum and between L. squamifrons and $C$. hamatus. Irrespective of acclimation, warming decreased energy expenditure for protein synthesis in P. brachycephalum, which corresponds to reduced whole-animal growth at temperatures $>5^{\circ} \mathrm{C}$. Warming doubled energy expenditure for protein synthesis in $L$. squamifrons but had no effect on $C$. hamatus indicating that $L$. squamifrons might benefit from warmer waters. The species-specific temperature effect on energy expenditure for protein synthesis is discussed to mirror thermal sensitivity of whole-animal growth performance, thereby paralleling the degree of cold adaptation. Clearly more data are necessary including measurements at narrower temperature steps particularly for $C$. hamatus and an increased species' number per ecotype to reinforce presented link between cellular and whole-animal thermal sensitivity.
\end{abstract}

Keywords Temperature $\cdot$ Polar $\cdot$ Icefish $\cdot$ Cell respiration $\cdot$ Cycloheximide $\cdot$ Protein synthesis

\section{Introduction}

The development of the Antarctic Circumpolar Current and the resulting isolation and cooling of the Southern Ocean created the coldest marine environment. Antarctic waters are characterized by temperatures as low as $-1.9^{\circ} \mathrm{C}$ with little seasonal variations and high oxygen content. The Antarctic

Electronic supplementary material The online version of this article (https://doi.org/10.1007/s00300-020-02752-w) contains supplementary material, which is available to authorized users.

Gisela Lannig

Gisela.Lannig@awi.de

1 Integrative Ecophysiology, Alfred Wegener Institute Helmholtz Center for Polar \& Marine Research, 27570 Bremerhaven, Germany

2 Australian Institute of Marine Science, Darwin, NT 0811, Australia fish fauna, which is largely dominated by the endemic family Notothenioidae, has evolved distinctive physiological specializations such as anti-freeze proteins and high mitochondrial densities (Johnston 2003; for review see Clarke and Johnston 1996; Pörtner 2006; Verde et al. 2006; Mintenbeck et al. 2012 and references therein). Adaptation to this unique environment, however, comes at the cost of increased temperature sensitivity compared to temperate fish (Pörtner and Peck 2010; Convey and Peck 2019). A study of thermal tolerance of marine benthic groups across latitudes highlighted that Antarctic species are less resistant to warming than temperate species, and the authors suggested that an organism's response to changing temperature is strongly influenced by the degree of experienced environmental temperature fluctuations (Peck et al. 2014). One of the most extreme biochemical traits among Antarctic fish species is the loss of red blood cells and haemoglobin in members of the family Channichthyidae, the white-blooded crocodile 
icefish (Ruud 1954; see also Kock 2005a, b). White-blooded icefish perform just as well as red-blooded notothenioids due to alternative modifications, e.g. of the cardiovascular system (diPrisco 2000; Sidell and O'Brien 2006; Garofalo et al. 2009). However, channichthyid icefish reach their critical thermal maximum $\left(\mathrm{CT}_{\max }\right.$, defined as the temperature at which the animal loses its equilibrium) at lower temperatures (Beers and Sidell 2011) and suffer from greater oxidative damage during warming (Mueller et al. 2012) than most notothenioids. Antarctic fishes, particularly icefishes, may therefore be restricted in their ability to respond to temperature variations, which makes them susceptible to global warming (Beers and Jayasundara 2015). Given sufficiently long durations of exposure, within certain thermal limits, many species (including Antarctic species) can cope with temperature change by physiological acclimation/acclimatization (Johnston and Dunn 1987; Guderley 1990; Lannig et al. 2003; Pörtner et al. 2008; Schulte et al. 2011; Peck et al. 2014). After warm acclimation $\left(4^{\circ} \mathrm{C}\right)$ for several days/ weeks, $\mathrm{CT}_{\max }$ was increased by approximately 2 to $4{ }^{\circ} \mathrm{C}$ in several Antarctic notothenioids (Beers und Jayasundara 2015). Despite their cold-stenothermy, members of the Antarctic fish fauna can, at least to a certain degree, adjust aerobic metabolism (e.g. mitochondrial capacities) to compensate for the impact of temperature on metabolic processes and support a new metabolic steady state. This was shown for notothenioids, e.g. the bald rockcod Pagothenia borchgrevinki (Seebacher et al. 2005; Franklin et al. 2007), the marbled rockcod Notothenia rossii, the grey rockcod Lepidonotothen squamifrons (Strobel et al. 2013) and a zoarcid, the Antarctic eelpout Pachycara brachycephalum (Lannig et al. 2005; Storch et al. 2005; Brodte et al. 2006a).

Cellular energy homeostasis is critical for the organism's survival, and different cellular functions exhibit different sensitivity to limited energy supply (Atkinson 1977). Under environmental stress conditions, cellular energy expenditures are commonly reallocated between energy-consuming processes to conserve ATP and maintain the most vital cellular functions. Protein turnover is a major contributor to cellular ATP turnover. In mammals, approximately 20-24\% of whole-animal respiration can be attributed to protein synthesis (Rolfe and Brown 1997). During energy deficiency (e.g. hypoxia) when energy-consuming processes compete for the available energy, protein synthesis is a key cellular function and among the first to be depressed (Boutilier 2001 and references therein). In fish, liver represents the central site of secondary metabolism and relies upon a very active protein synthesis machinery (Houlihan 1991). The energy metabolism of hepatocytes responds sensitively to energy disturbances caused by environmental stress. Under hypoxia, oxygen consumption and protein synthesis were depressed in liver cells of the rainbow trout Oncorhynchus mykiss (Pannevis and Houlihan 1992). Langenbuch and Pörtner (2003) showed that under hypercapnic conditions and associated extracellular acidosis cellular energy expenditure for protein synthesis was downregulated in Antarctic fish hepatocytes. The role of energy reallocation to cellular protein synthesis in response to temperature change is not well understood. Mark et al. (2005) investigated the effect of temperature on hepatic energy budget in Antarctic fish to explore a possible role of cellular energy metabolism in co-defining thermal tolerance. However, cellular energy budgets were mostly maintained over the investigated temperature range $\left(0{ }^{\circ} \mathrm{C}-15^{\circ} \mathrm{C}\right)$, and the authors found no clear impact of temperature on energy allocation to protein synthesis. They concluded that shifts in cellular energy allocation might become effective first during systemic hypoxemia. However, they observed significantly elevated energy allocation to protein synthesis in the high compared to the sub-Antarctic fish species, indicating cold-compensated protein synthesis capacities. Peck (2018), who summarized recent knowledge on cold adaptation in the Antarctic fauna, highlighted that growth rates for Antarctic animals are slower than expected from the normal effects of temperature on biological processes $\left(\mathrm{Q}_{10}\right.$ relationship). He previously suggested, that at temperatures around $0{ }^{\circ} \mathrm{C}$ "protein synthesis and folding problems cause the slowing of rates beyond expected temperature effects" and emphasized research focusing on the underlying mechanisms (Peck 2016). Growth relies on both excess substrate and energy availability at low baseline costs. Temperature-dependent growth performance of marine ectotherms follows an inverse U-shaped curve (e.g. Fonds et al. 1992; Pörtner et al. 2001; Brodte et al. 2006a; Fly and Hilbish 2013; Gräns et al. 2014). Maximum growth seems to occur at temperatures prior to the acute exponential rise in whole-animal oxygen consumption and, where cellular baseline costs are minimal (Pörtner et al. 2008; Pörtner and Lannig 2009). In addition to aerobic energy metabolism, temperature affects as well feeding behaviour and food conversion efficiency and, obviously, the factors are positively correlated with growth performance (Fonds et al. 1989; Fonds et al. 1992; Brodte et al. 2006a; Sandersfeld et al. 2015; see also Peck 2018). After long-term acclimation to different temperatures $\left(0,2,4\right.$ and $\left.6{ }^{\circ} \mathrm{C}\right), P$. brachycephalum showed highest growth and food conversion efficiency at $4{ }^{\circ} \mathrm{C}$, whereas routine metabolic rates did not differ between warm- and non-acclimated $\left(0{ }^{\circ} \mathrm{C}\right)$ specimens (Brodte et al. 2006a). The authors who also calculated temperature-dependent whole-animal budgets showed that energy allocation to growth was high at the temperature of optimal growth and reduced at $6{ }^{\circ} \mathrm{C}$ accompanied by increased energetic demand for maintenance. Similarly, after acclimation to different temperatures $(0,1,2$ and $4{ }^{\circ} \mathrm{C}$ ) routine metabolic rates of the high-Antarctic emerald rockcod Trematomus bernacchii returned to baseline levels at $0{ }^{\circ} \mathrm{C}$ (Sandersfeld et al. 2015). However, growth 
and food conversion ratios were significantly decreased in $2{ }^{\circ} \mathrm{C}$ - and $4{ }^{\circ} \mathrm{C}$-acclimated $T$. bernacchii which coincided with increased energy allocation to maintenance. Against the background that cellular protein synthesis requires a substantial amount of energy and responds most sensitive to changes in energy supply, one might expect a link between temperature-dependent whole-animal growth performance and cellular energy expenditure for protein synthesis. The aim of the present study was, therefore, to investigate if thermal sensitivity of cellular energy allocation to protein synthesis mirrors thermal tolerance at the organism level with respect to temperature-dependent growth. We investigated temperature-dependent changes in cell metabolism of three Antarctic fish species: the circumpolar-distributed Antarctic eelpout Pachycara brachycephalum, the subAntarctic notothenioid fish Lepidonotothen squamifrons and the high-Antarctic white-blooded icefish Chionodraco hamatus. In contrast to notothenioids, $P$. brachycephalum is characterized by a higher tolerance to warming (van Dijk et al. 1999; Mark et al. 2002; Bilyk and DeVries 2011), and its main distribution seems to be related to water temperatures above $0{ }^{\circ} \mathrm{C}$ (Anderson 1989; Brodte et al. 2006b). In $P$. brachycephalum whole-animal physiology and thermal tolerance are very well studied. Based on the findings of similar routine metabolic rates after long-term acclimation to different temperatures (Brodte et al. 2006a) but highest growth rates at $3-5{ }^{\circ} \mathrm{C}$ (Brodte et al. 2006a; Windisch et al. 2014), our first working hypothesis was that cellular oxygen consumption allocated to protein synthesis shows highest energy expenditure at the optimal temperature for growth in P. brachycephalum. We hypothesized further that warmacclimated $P$. brachycephalum shows higher energy expenditure for protein synthesis than non-acclimated specimens. Unlike in P. brachycephalum, whole-animal physiology and thermal tolerance are not well studied in $L$. squamifrons and C. hamatus. If our first hypothesis holds true, investigations on cell metabolism of $L$. squamifrons and $C$. hamatus should reveal different thermal sensitivity in cellular energy allocation to protein synthesis in accordance with the degree of cold adaptation of the two species. Lepidonotothen squamifrons inhabits the shelf and upper slopes of the sub-Antarctic islands between $45^{\circ}$ and $55^{\circ} \mathrm{S}$ (Gon and Heemstra 1990) with water temperatures ranging from 0.7 to $3.5^{\circ} \mathrm{C}$ (Ward 1989; Pakhomov et al. 2006). Chionodraco hamatus lives in the stable-cold circum-Antarctic waters and is mainly recorded on the continental shelf of East Antarctica $\left(60^{\circ} \mathrm{S}\right)$ with temperatures of $<0{ }^{\circ} \mathrm{C}$ year-round (Iwami and Kock 1990; Gon and Heemstra 1990). Against this ecological background and species' adaptation to their respective average habitat temperature we tested our second hypothesis that cellular energy expenditure for protein synthesis peaks at a lower temperature in C. hamatus than in L. squamifrons.

\section{Materials and methods}

\section{Animal collection and maintenance}

The Antarctic eelpout $P$. brachycephalum was collected at the Antarctic Peninsula, close to King George Island $\left(62^{\circ} 19^{\prime} \mathrm{S} ; 58^{\circ} 33^{\prime} \mathrm{W}\right)$ during the RV Polarstern Antarctic expedition ANT XXV/4-5 in April 2009. Animals were caught by baited traps at depths between 419 and $466 \mathrm{~m}$ at $0.6{ }^{\circ} \mathrm{C}$ and 34.4 PSU. Animals were kept on board in wellaerated $150 \mathrm{~L}$ aquaria tanks at ambient conditions $\left(0 \pm 0.6^{\circ} \mathrm{C}\right.$ and 34.2 $\pm 0.2 \mathrm{PSU}$ ) and transported to the institutional aquarium systems at Bremerhaven. In November 2009, randomly selected individuals were exposed to elevated temperature $\left(5^{\circ} \mathrm{C}\right.$, warm acclimation) for one year while control animals were kept at $0{ }^{\circ} \mathrm{C}$. Animals were warm-exposed at a rate of $1{ }^{\circ} \mathrm{C}$ day ${ }^{-1}$ until the target temperature of $5{ }^{\circ} \mathrm{C}$ was reached. During the 1-year exposure two animals died, which corresponds to a $7 \%$ mortality. Water parameters were measured at least three times a week (Table 1). Once a week animals were fed ad libitum with frozen North Sea shrimps Crangon (Fa. Erdmann, Ritterhude, Germany). The organismal measurements are shown in Table 2. The hepatosomatic index (HSI) was determined as (Brodte et al. 2006a).

$$
\text { HSI }=\frac{\text { liver weight }[\mathrm{g}]}{(\text { body weight }- \text { stomach content })[\mathrm{g}]} \times 100 .
$$

In 2015, we performed a subsequent cell study with $P$. brachycephalum for a comparative approach of experimental setups (intermittent-flow respirometry $v s$. closed system respirometry, see below). The fish were from the same catch (expedition ANT XXV/4-5 in 2009) and were maintained throughout under control conditions $\left(0{ }^{\circ} \mathrm{C}\right)$ in
Table 1 Parameters of seawater during the 1-year acclimation of Pachycara brachycephalum to $0{ }^{\circ} \mathrm{C}$ (control) and $5{ }^{\circ} \mathrm{C}$ (warm acclimation): ammonium $\left(\mathrm{NH}_{4}^{+}\right)$, nitrite $\left(\mathrm{NO}_{2}{ }^{-}\right)$, sample size $(n)$

\begin{tabular}{lllll}
\hline Treatment & Temperature $\left({ }^{\circ} \mathrm{C}\right)$ & Salinity $(\mathrm{PSU})$ & $\mathrm{NH}_{4}^{+}\left(\mathrm{mg} \mathrm{L}^{-1}\right)$ & $\mathrm{NO}_{2}^{-}\left(\mathrm{mg} \mathrm{L}^{-1}\right)$ \\
\hline $\begin{array}{l}\text { Control }\left(0^{\circ} \mathrm{C}\right) \\
(n=138-160)\end{array}$ & $0.8 \pm 0.3$ & $31.6 \pm 1.9$ & $0.10 \pm 0.02$ & $0.03 \pm 0.01$ \\
$\begin{array}{l}\text { Warm acclimation } \\
\left(5{ }^{\circ} \mathrm{C}\right)(n=138-\end{array}$ & $5.6 \pm 0.5$ & $30.8 \pm 0.7$ & $0.10 \pm 0.02$ & $0.02 \pm 0.01$ \\
$158)$ & & & \\
\hline
\end{tabular}

Values are given as means $\pm \mathrm{SD}$ 
Table 2 Organismal measurements and sample size (n) of Pachycara brachycephalum after 1-year acclimation to $0{ }^{\circ} \mathrm{C}$ (control) and $5{ }^{\circ} \mathrm{C}($ warm acclimation)

\begin{tabular}{lcccc}
\hline Treatment & Length $(\mathrm{cm})$ & Body mass $(\mathrm{g})$ & Condition factor ${ }^{\mathrm{a}}$ & $\begin{array}{l}\text { Hepatosomatic index } \\
(\text { HSI })\end{array}$ \\
\hline Control $\left(0^{\circ} \mathrm{C}\right)$ & $20.6 \pm 1.2$ & $30.7 \pm 6.9$ & $0.3 \pm 0.02$ & $2.6 \pm 0.6$ \\
Warm acclimation $\left(5^{\circ} \mathrm{C}\right)$ & $24.2 \pm 2.3$ & $45.1 \pm 7.3$ & $0.3 \pm 0.06$ & $1.7 \pm 0.5^{*}$ \\
\hline
\end{tabular}

${ }^{a}$ Fulton's condition factor was calculated with the fresh body mass without stomach content

*Significant difference to HSI of P. brachycephalum at $0{ }^{\circ} \mathrm{C}$. Values are given as means $\pm \mathrm{SD}$

the institutional aquarium system (see details above). Organismal measurements were as follow: length $23.1 \pm 2.9 \mathrm{~cm}$, body mass $52.0 \pm 20.3 \mathrm{~g}$, condition factor $0.4 \pm 0.04$, and HSI of $3.9 \pm 0.7(n=18)$.

A second suite of cellular investigations was performed with primary hepatocytes of the grey rockcod Lepidonotothen squamifrons and the white-blooded icefish Chionodraco hamatus. Both species were caught by bottom trawls during the RV Polarstern Antarctic expedition ANT XXVII/3 in spring 2011. L. squamifrons (animal length $25.4 \pm 3.1 \mathrm{~cm}$, body mass $228.9 \pm 99.9 \mathrm{~g}$ and HSI of $1.6 \pm 0.4, n=15$ ) was caught at around $300 \mathrm{~m}$ water depth at $2.1^{\circ} \mathrm{C}$ and $34.4 \mathrm{PSU}$ $\left(53^{\circ} 24^{\prime} \mathrm{S} ; 42^{\circ} 40^{\prime} \mathrm{W}\right)$. Individuals of $C$. hamatus (animal length $33.1 \pm 1.5 \mathrm{~cm}$, body mass $237.8 \pm 41.8 \mathrm{~g}$ and HSI of $3.1 \pm 1.5, n=7-8$ ) were caught between 100 and $280 \mathrm{~m}$ water depth at $-1.8 \pm 0.2{ }^{\circ} \mathrm{C}$ and $34.1 \pm 0.2 \mathrm{PSU}$ (daily trawls, $\left.70^{\circ} 19^{\prime}-53^{\prime} \mathrm{S} ; 10^{\circ} 22^{\prime}-52^{\prime} \mathrm{W}\right)$. The experiments were conducted directly on board of the RV Polarstern, and animals were only kept shortly (1 to 2 days) in the above-mentioned aquaria tanks prior to experiments. Stress response to trawling such as increasing levels of stress hormones (mainly cortisol and epinephrine) did not interfere with our measurements on isolated hepatocytes. Due to the experimental procedure of cell isolation incl. several washing steps and a onehour incubation of the final cell homogenate (see below) any stress-induced cellular changes because of altered plasma composition in vivo should be negligible at the time of the respiration measurements.

\section{Determination of temperature-dependent cell metabolism}

\section{Buffers}

All buffers were adjusted to $\mathrm{pH} 7.4\left(5^{\circ} \mathrm{C}\right)$ and supplemented with $\mathrm{NaCl}$ to reach the species-specific osmolality: $340 \mathrm{mOsm} \mathrm{kg}^{-1}$ for $P$. brachycephalum, $360 \mathrm{mOsm} \mathrm{kg}^{-1}$ for L. squamifrons and $550 \mathrm{mOsm} \mathrm{kg}^{-1}$ for C. hamatus. Blood osmolality was determined in serum using a vapour pressure osmometer (Wescor 5500, ELITech, Logan, Utah/USA). All chemicals and media were obtained from Sigma-Aldrich (Darmstadt, Germany).
The following buffers were used:

Isolation buffer ( buffer $_{\text {iso }}$ ): Hanks balanced salt solution without magnesium and calcium enriched with $10 \mathrm{mM}$ 4-(2-hydroxyethyl)-1-piperazineethanesulfonic acid (HEPES) and species-specific $\mathrm{NaCl}$ concentration.

Washing buffer ( buffer $_{\text {wash }}$ ): buffer $_{\text {iso }}$ supplemented with $5 \mathrm{mM}$ EDTA to bind $\mathrm{Ca}^{2+}, \mathrm{Mg}^{2+}$ and accelerate disintegration of the tissue.

Digestion buffer 1 (buffer dig1 $_{1}$ ): buffer iso $_{\text {freshly supple- }}$ mented with $1 \%$ BSA (w:v) and $1500 \mathrm{U} \mathrm{mL}^{-1}$ collagenase Type $1 \mathrm{~A}$.

Digestion buffer 2 (buffer $\left._{\text {dig } 2}\right)$ : buffer $_{\text {iso }}$ freshly supplemented with $1 \%$ BSA (w:v) and $1125 \mathrm{U} \mathrm{mL}^{-1}$ collagenase Type 1A.

Centrifugation buffer ( buffer $\left._{\text {cent }}\right)$ : buffer $_{\text {iso }}$ freshly supplemented with $1 \%$ BSA (w:v) and $1.5 \mathrm{mM} \mathrm{CaCl}_{2}$ to re-add calcium ions and favour cell recovery and adhesion.

Culture medium (CM): Leibovitz L-15 medium (with L-glutamine) supplemented with $10 \mathrm{mM}$ HEPES, species-specific $\mathrm{NaCl}$ concentration, $5 \mathrm{mM}$ D-glucose, $1 \%$ penicillin/streptomycin (v:v) and $10 \%$ fetal bovine serum (v:v, FBS).

Measurement medium (MM): Leibovitz L-15 medium (with L-glutamine) supplemented with $10 \mathrm{mM}$ HEPES and species-specific $\mathrm{NaCl}$ concentration.

\section{Cell isolation}

The isolation of hepatocytes was modified after Mommsen et al. (1994). Briefly, fish were anaesthetized with MS-222 (3-Amino-benzoic-methanesulfonate, $0.5 \mathrm{~g} \mathrm{~L}^{-1}$ ). After determination of body length and body mass, fish were killed by a cut through the spine, and the liver was carefully excised and transferred into a Petri dish with ice-cold buffer $_{\text {iso }}\left(4 \mathrm{~mL} \mathrm{~g}^{-1}\right.$ tissue, at least $5 \mathrm{~mL}$ ). Due to the small liver sizes of $P$. brachycephalum, livers of two specimens were pooled in approximately half of the experiments to gain sufficient cell yield for the measurements. To remove blood cells, buffer $_{\text {wash }}$ was repeatedly injected into the liver via the hepatic vascular system. Afterwards, the liver was perfused with buffer $_{\operatorname{dig} 1}\left(2 \mathrm{~mL} \mathrm{~g}^{-1}\right.$ tissue, at least $5 \mathrm{~mL}$, for 5-10 min) 
to remove EDTA, which inhibits the functioning of collagenase. The tissue digestion was initiated by placing the liver into buffer ${ }_{\text {dig } 2}\left(2 \mathrm{~mL} \mathrm{~g}^{-1}\right.$ tissue, at least $\left.5 \mathrm{~mL}\right)$ and shaking at $100 \mathrm{rpm}$ on ice. The peritoneal tissue was removed, and the liver was periodically massaged with a cut Pasteur pipette. When total disintegration was achieved (after $\sim 90 \mathrm{~min}$ ), the cell suspension was filtered through a two-stage nylon mesh filtering system $(250$ and $70 \mu \mathrm{m})$. Cell pellets were collected and washed $(4 \mathrm{x})$ by repeated low-speed centrifugation $\left(4 \mathrm{~min}\right.$ at $0{ }^{\circ} \mathrm{C}$ and $60 \times g$ or $100 \times g$ for lipid-rich livers). During washing steps, cell pellets were re-suspended twice in buffer ${ }_{\text {cent }}$ and finally twice in CM. Prior to respiration measurements, cell suspensions were adjusted to $10^{7}$ cells $\mathrm{mL}^{-1}$ in $\mathrm{CM}$ and shaken on ice (70 rpm) for at least $1 \mathrm{~h}$ to allow for recovery from handling stress. Cell viability, which was assessed using a Fuchs-Rosenthal counting chamber and a standard trypan-blue exclusion assay, was similar between species, with $96.1 \pm 1.8 \%$ (P. brachycephalum, $n=14$, common mean for $0{ }^{\circ} \mathrm{C}$ - and $5{ }^{\circ} \mathrm{C}$-acclimated fish), $95.0 \pm 2.3 \%$ ( $P$. brachycephalum, $n=12$, subsequent study in 2015), $94.1 \pm 2.8 \%(C$. hamatus, $n=6)$ and $98.3 \pm 1.2 \%$ (L. squamifrons, $n=12$ ).

\section{Online monitoring of cell respiration via intermittent-flow respirometry}

The effect of temperature on cell metabolism was determined with a Si-sensor-chip device, the BIONAS $2500^{\circledR}$ analysing system (BIONAS GmbH, Germany). The system consists of two measurement modules, BM1 and BM2. The sensor chip (BIONAS Discovery $\left.{ }^{\mathrm{TM}} \mathrm{SC} 1000\right)$ monitors oxygen consumption by planar electrodes (Clark-type) and cell adhesion via impedance measurements by interdigitated electrode structures (IDESs). The intermittent-flow system with stop-and-go cycles allows replacement of medium at a periodic cycle. In addition to the online profiling of cell parameters, the BIONAS device monitors the temperature during experimentation in situ (for more details to the system see Thedinga et al. 2007). Freshly isolated cells were seeded directly on the metabolic chip (3.5 million cells chip ${ }^{-1}$ for $P$. brachycephalum and 5.7 million cells chip ${ }^{-1}$ for L. squamifrons. and C. hamatus) which was pre-coated with collagen ( $1: 10$ diluted (v:v) collagen R solution $0.2 \%$, Type I, SERVA 47254). For each cell preparation we prepared 4 to 6 chips, whereof finally two chips were used for measurements. Preliminary tests revealed improper cell adhesion after 12-24 h incubation/seeding time. Due to time constraints, we thus used specific membrane inlays $(0.4 \mu \mathrm{m}$ pore size, BIONAS GmbH) to prevent cell loss during medium exchange. Measurement medium (MM) was exchanged at a rate of 56

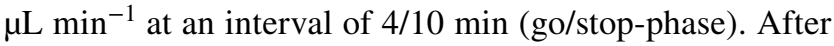
sufficient recording time of total respiration, hepatocytes measured with BM1 were exposed to MM supplemented with $100 \mu \mathrm{M}$ cycloheximide. Cycloheximide is a eukaryote protein synthesis inhibitor, and its inhibition effect was shown to be maximal after $1 \mathrm{~h}$ of incubation (Langenbuch and Pörtner 2003; Cherkasov et al. 2006). After sufficient recording time of inhibited respiration, temperature was changed, and the procedure was repeated with BM2 to determine fractional costs of protein synthesis at the second assay temperature. Finally, cells were killed by adding $0.2 \%$ Triton X-100 (v:v) to the medium. Following the manufacturer's instructions, the first two hours of an experimental run were discarded to allow for system stabilization. Respiration rates were analysed by the integrated software (BIONAS GmbH). To calculate respiration rates, we used the rates of 15 measurement cycles prior to and after the change of temperature and medium, respectively. Oxygen consumption allocated to protein synthesis was calculated as the difference of total respiration minus cycloheximide-inhibited respiration. The BIONAS system does not use internal calibration of the absolute $\mathrm{O}_{2}$ levels, and the respiration rates are, therefore, shown in the device-specific units $\left(\mathrm{pA} \mathrm{s}^{-1}\right)$.

The experiments with $P$. brachycephalum were performed at the temperature of optimal whole-animal growth $\left(5.4 \pm 0.1{ }^{\circ} \mathrm{C}, n=14\right)$ and a warmer, suboptimal temperature $\left(9.9 \pm 0.2{ }^{\circ} \mathrm{C}, n=14\right)$. The experiments with $L$. squamifrons and $C$. hamatus were performed close to the environmental temperature $\left(1.0 \pm 0.2^{\circ} \mathrm{C}, n=17-18\right)$ and at an elevated temperature $\left(5.5 \pm 0.2^{\circ} \mathrm{C}, n=17-18\right)$, which was assumed to be suboptimal for $C$. hamatus. Experimental temperatures were controlled by placing the BIONAS device into a refrigerator with an additional cooling coil that was connected to an external thermostat. The lowest achievable temperature was $1{ }^{\circ} \mathrm{C}$. After temperature was set to the new target temperature, it took around $1.5 \mathrm{~h}$ to become stabilized. We swapped starting temperatures between measurements to account for a possible time effect, which, however, was negligible.

\section{Determination of cell respiration via closed system respirometry}

We performed the above-mentioned subsequent study on $P$. brachycephalum and repeated experiments using the commonly used closed system respirometry. Contrasting to literature findings, where no significant effect of temperature on cellular energy budget could be observed (Pannevis and Houlihan 1992; Mark et al. 2005; Lannig et al. 2010), we found a clear temperature impact on cellular energy allocation to protein synthesis. The subsequent study aimed to test if the contrasting findings are associated with different respirometry methods used (intermittent-flow vs. closed system respirometry). For this, temperature impact on cell metabolism was determined using a closed system respirometry setup with micro-optodes from PreSens (PreSens GmbH, Germany) (for more details to the setup see 
Langenbuch and Pörtner 2003; Mark et al. 2005; Lannig et al. 2010). Prior to measurements, the cell suspension $(1.2 \mathrm{~mL})$ was centrifuged $\left(3 \mathrm{~min}\right.$ at $0{ }^{\circ} \mathrm{C}$ and $\left.100 \mathrm{~g}\right)$, and the supernatant was replaced by fresh buffer. We did preliminary tests where the 1-h cycloheximide incubation was performed inside the chamber. The parallel measurements of cell respiration with and without cycloheximide revealed that cell respiration was more affected by time than by cycloheximide inhibition, even though final oxygen levels did not drop below $70 \%$. Cells were, however, unaffected and showed stable respiration rates when kept on ice for up to $4 \mathrm{~h}$ after cell isolation. We thus followed the protocol by Langenbuch and Pörtner (2003) and performed the cycloheximide incubation on a separate cell cohort outside the respiration chamber. After 1-h incubation both non-inhibited control cells and cycloheximide-incubated cells were measured simultaneously, and oxygen consumption allocated to protein synthesis was calculated as the difference of respiration of control cells minus respiration of cycloheximide-inhibited cells. In this study, temperature impact on hepatic cell metabolism of $P$. brachycephalum was measured at three temperatures, $0{ }^{\circ} \mathrm{C}, 5^{\circ} \mathrm{C}$ and $10^{\circ} \mathrm{C}$. The additional measurements at $0{ }^{\circ} \mathrm{C}$ aimed to cover the entire thermal tolerance range of $P$. brachycephalum with $0{ }^{\circ} \mathrm{C}$ representing a suboptimal temperature for whole-animal growth at the cold side of its thermal tolerance range. At each temperature, a two-point calibration was performed using saturated sodium sulphide solution for $0 \%$ and air-bubbled medium for $100 \%$ air saturation. Cellular oxygen consumption $\left(\mathrm{nmol} \mathrm{O}_{2} \mathrm{~min}^{-1}\right.$ $10^{6}$ cells $^{-1}$ ) and energy expenditure for protein synthesis ( $\%$ to total cell respiration) was calculated as described in detail by Lannig et al. (2010).

\section{Statistics}

Statistical analyses were carried out using SigmaStat for Windows (Version 3.5). One-way ANOVA on Ranks was used to test for the effect of acclimation temperature on HSI of P. brachycephalum. Two-way ANOVA followed by Holm-Sidak test was used to test for the effect of assay temperature on cellular respiration rates and the fractional costs for protein synthesis dependent on acclimation temperature and species, respectively. Since acclimation temperature had no impact on cell physiology, the datasets were pooled and tested again with one-way ANOVA followed by a Holm-Sidak test for the effect of assay temperature. The pooled dataset was used to test for the effect of respirometry method and assay temperature on the fractional costs for protein synthesis using two-way ANOVA followed by a Holm-Sidak test. One-Way ANOVA followed by a Holm-Sidak test was used to test for the effect of assay temperature on cell metabolism of $P$. brachycephalum in the subsequent study in 2015. If assumptions for ANOVA were not fulfilled, data were log transformed to meet the criteria for normality and equality of variances. In all analyses, the effect was considered significant if $p<0.05$. All data are presented as mean values \pm standard deviation $(\mathrm{SD})$.

\section{Results}

\section{Impact of temperature on cell metabolism of $P$. brachycephalum}

\section{Impact of acclimation temperature}

Long-term warm acclimation to $5{ }^{\circ} \mathrm{C}$ led to a significantly lowered HSI (Table 2, Kruskal-Wallis test, $H_{1}=8.747$, $p=0.003$ ) but did not affect hepatic cell respiration of the Antarctic eelpout $P$. brachycephalum. When measured at the same assay temperature, primary hepatocytes showed similar respiration rates and energy expenditure for protein synthesis regardless of acclimation temperature (ANOVA, total respiration: $F_{1}=0.335, p=0.568$; respiration allocated to protein synthesis: $F_{1}=0.0165, p=0.900$; energy expenditure for protein synthesis: $F_{1}=1.490, p=0.246$ ). For better clarity, we thus pooled the data (Fig. 1a-c), and the acclimation-specific data can be seen in Online Resource 1 (ESM 1).

\section{Impact of respirometry setup}

The intermittent-flow respirometry was a more sensitive method to detect temperature-induced changes in cellular energy budget compared to the closed system respirometry. Figure 1 shows datasets of $P$. brachycephalum that were obtained using intermittent-flow respirometry (Fig. 1a-c) or closed system respirometry (Fig. 1d-f). Both methods revealed a similar response of primary hepatocytes to acute warming, and the values for temperature-dependent fractional costs of protein synthesis were not affected by the method used (ANOVA, $F_{1}=0.0137, p=0.908$ ). However, the degree of changes was less pronounced in the results that were obtained using closed system respirometry. Compared to the intermittent-flow respirometry that revealed significant changes in both total respiration and energy expenditure for protein synthesis between 5 and $10{ }^{\circ} \mathrm{C}$ (ANOVA, $F_{1}=17.131, p<0.001$ and $F_{1}=51.970, p<0.001$, respectively), the closed system respirometry revealed only significant changes between total cell respiration at $0{ }^{\circ} \mathrm{C}$ and $10{ }^{\circ} \mathrm{C}$ (ANOVA, $F_{2}=6.956, p=0.005$ ).

\section{Impact of assay temperature}

Acute warming from 5 to $10{ }^{\circ} \mathrm{C}$ significantly increased hepatic respiration rates of $P$. brachycephalum by a factor of 1.8 (ANOVA, $F_{1}=17.131, p<0.001$, Fig. 1 a) resulting 
a

intermittent-flow respirometry

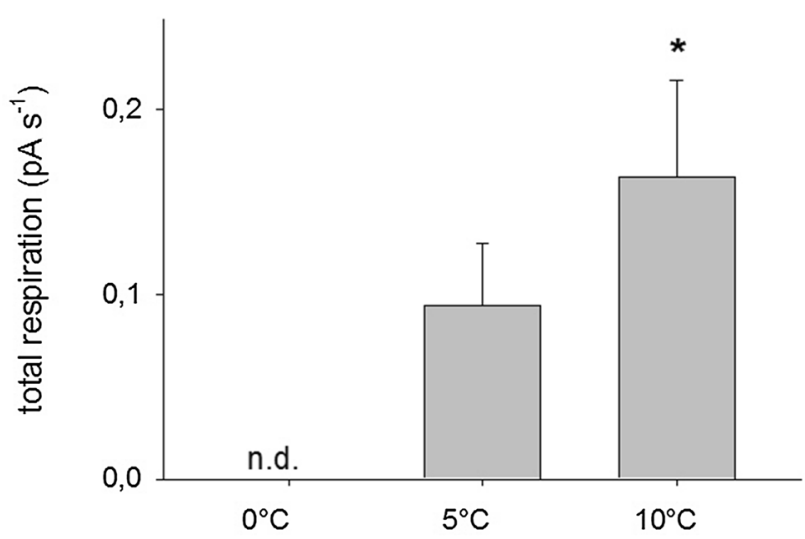

b

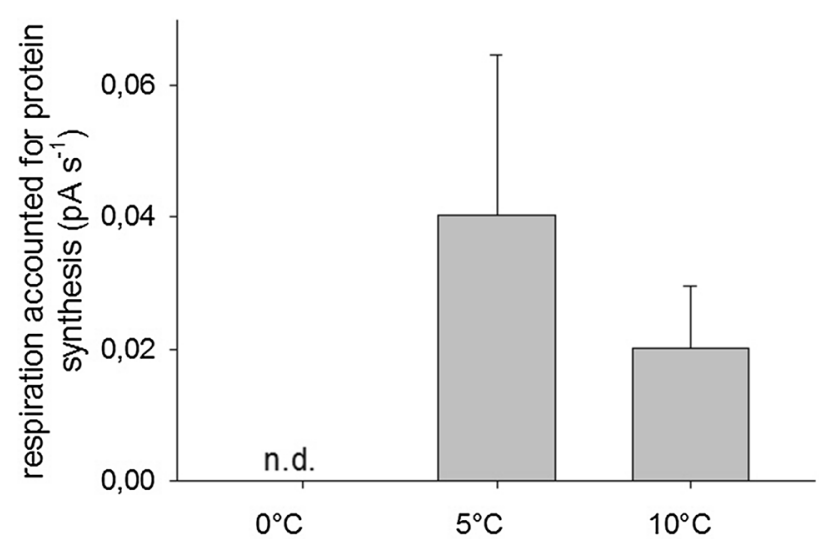

C

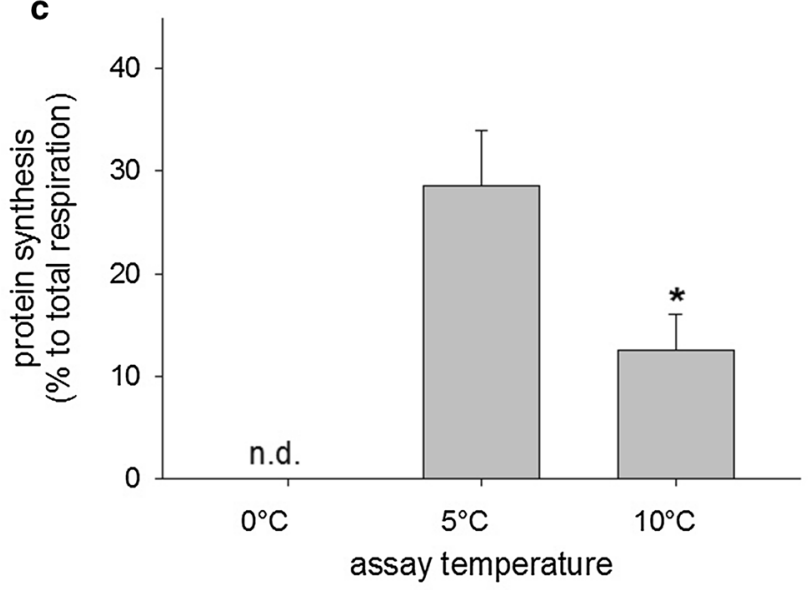

Fig. 1 Temperature-dependent changes in hepatic cell metabolism of Pachycara brachycephalum obtained using different respirometry setups, intermittent-flow $v s$. closed system respirometry. (a, d) total respiration rates, $(\mathbf{b}, \mathbf{e})$ cycloheximide-sensitive respiration rates and $(\mathbf{c}, \mathbf{f})$ fraction of protein synthesis to total respiration. *Data are sig- d closed system respirometry

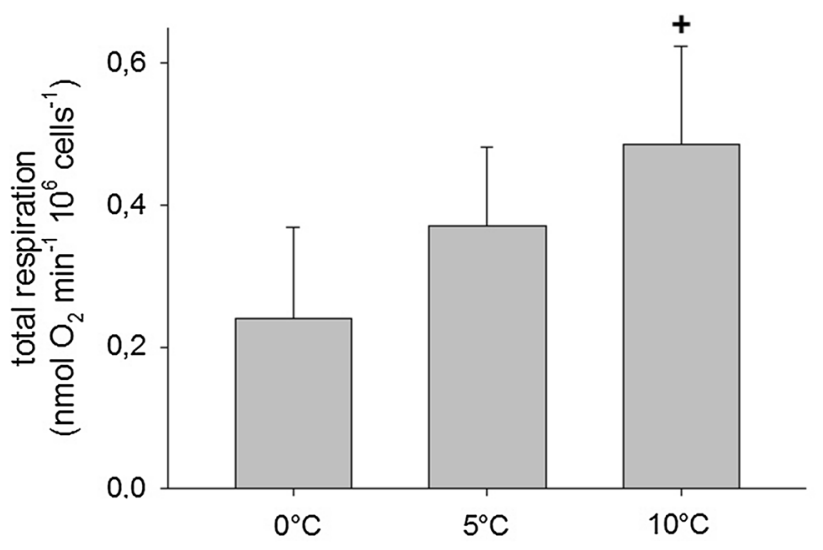

e

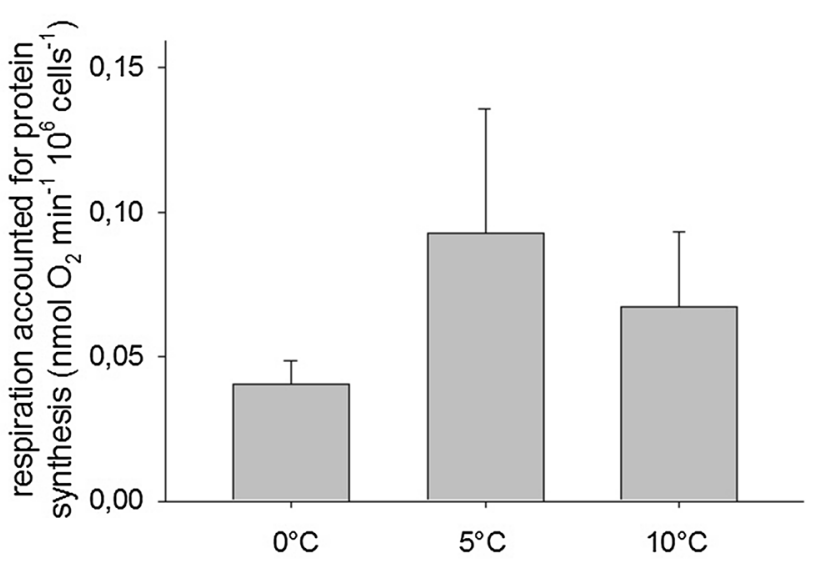

f

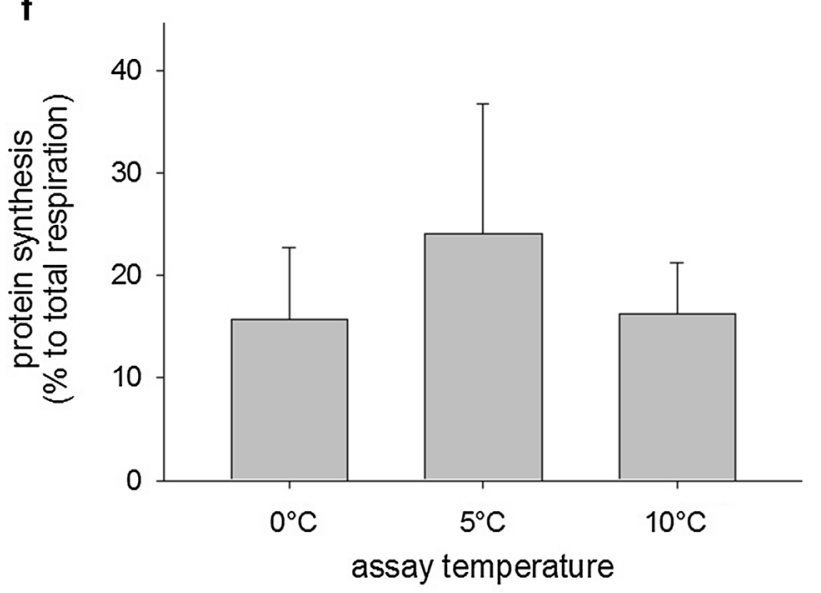

nificantly different to respective data at $5{ }^{\circ} \mathrm{C}$. ${ }^{+}$Data are significantly different to respective data at $0{ }^{\circ} \mathrm{C}$. n.d. indicates data were not determined. Values are means $\pm \mathrm{SD}, n=6$-14 (intermittent-flow respirometry) and $n=3-10$ (closed system respirometry) 
in a $Q_{10}$ of $3.1 \pm 0.6(n=14)$. In the same temperature range, the closed system respirometry revealed a lower rise in total cell respiration by a factor of $1.5\left(\mathrm{Q}_{10}\right.$ of $\left.2.4 \pm 0.5, n=6\right)$, and hepatic respiration at $10{ }^{\circ} \mathrm{C}$ was significantly elevated to respiration at $0{ }^{\circ} \mathrm{C}$ but not at $5{ }^{\circ} \mathrm{C}$ (ANOVA, $F_{2}=6.956$, $p=0.005$, followed by a Holm-Sidak test, $p=0.0012$ $\left(0{ }^{\circ} \mathrm{C}\right)$ and $p=0.0572\left(5{ }^{\circ} \mathrm{C}\right)$, Fig. 1d). Oxygen consumption allocated to protein synthesis showed a non-significant reduction after warming (ANOVA, $F_{1}=4.590, p=0.0502$, Fig. 1b) which resulted, however, in significantly lower energy expenditure for protein synthesis at $10^{\circ} \mathrm{C}$ than at $5{ }^{\circ} \mathrm{C}$ (ANOVA, $F_{1}=51.970, p<0.001$, Fig. $1 \mathrm{c}$ ). The fraction of protein synthesis to total respiration rates significantly decreased from $28.6 \pm 5.4 \%(n=6)$ to $12.5 \pm 3.6 \%$ $(n=10)$. The data that were obtained using the closed system respirometry with additional measurements at $0{ }^{\circ} \mathrm{C}$ (Fig. 1e, f) revealed the expected (albeit statistically non-significant) inverse U-shaped trend with highest cycloheximide-sensitive respiration and cellular energy expenditure for protein synthesis at the intermediate temperature (ANOVA, $F_{2}=2.420$, $p=0.139$ and $F_{2}=1.089, p=0.373$, respectively).

\section{Impact of temperature on cell metabolism of $L$. squamifrons and $C$. hamatus}

\section{Impact of assay temperature}

The warming-induced rise in cellular respiration rates was similar in the sub-Antarctic grey rockcod $L$. squamifrons and the high-Antarctic icefish $C$. hamatus resulting in an overall $\mathrm{Q}_{10}$ of $6.4 \pm 1.4(n=14)$. Warming from 1 to $5{ }^{\circ} \mathrm{C}$ significantly increased total cell respiration of $L$. squamifrons, by a factor of 2.1 and of $C$. hamatus, by a factor of 2.0 $\left(F_{1}=25.266, p<0.001\right.$, Fig. $\left.2 \mathrm{a}\right)$. In contrast, thermal sensitivity of cellular protein synthesis differed between species. Temperature sensitivity of energy expenditure for protein synthesis was affected by species with an interaction between the two factors (ANOVA, species: $F_{1}=18.483, p<0.001$; assay temperature: $F_{1}=1.984, p=0.178$; species $\mathrm{x}$ assay temperature: $\left.F_{1}=6.876, p=0.018\right)$. Species-specific oxygen consumption allocated to protein synthesis was affected by assay temperature (ANOVA, species: $F_{1}=1.512, p=0.237$; assay temperature: $F_{1}=11.709, p=0.003$; species $\mathrm{x}$ assay temperature: $\left.F_{1}=3.362, p=0.085\right)$. In L. squamifrons hepatic respiration rates allocated to protein synthesis were significantly elevated at $5{ }^{\circ} \mathrm{C}$ compared to $1{ }^{\circ} \mathrm{C}$ (Holm-Sidak test, $p=0.001$; Fig. 2 b) leading to a significant rise in energy expenditure for protein synthesis at $5{ }^{\circ} \mathrm{C}$ (Holm-Sidak test, $p<0.008$; Fig. 2c). In contrast, cycloheximide-sensitive respiration of primary hepatocytes from $C$. hamatus was only slightly increased by warming (Holm-Sidak test, $p=0.301$; Fig. 2b), resulting in a non-significant decrease in energy

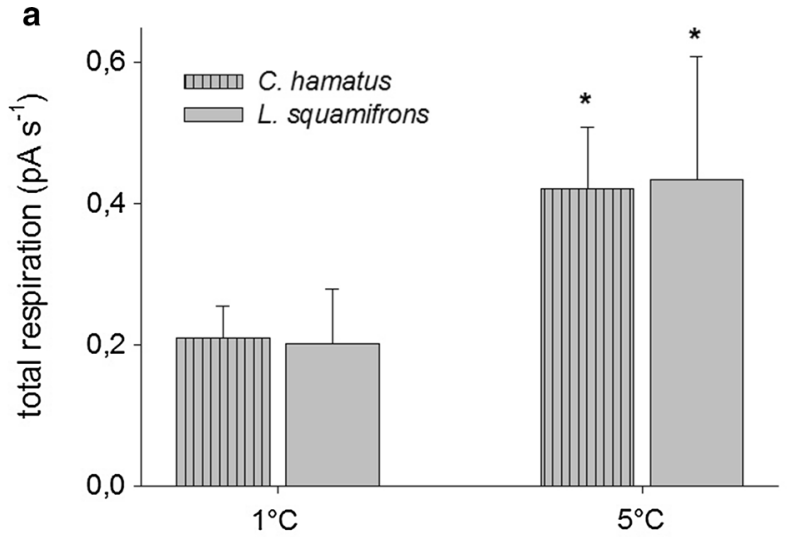

b
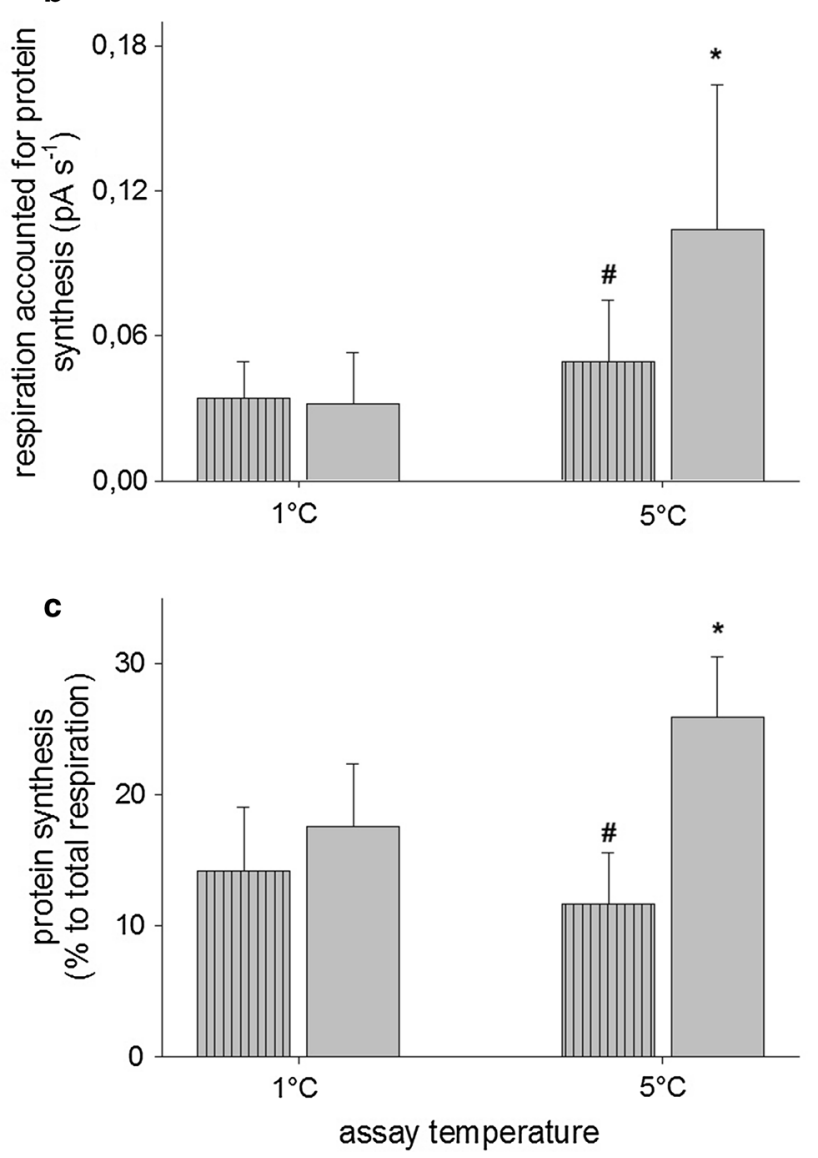

Fig. 2 Temperature-dependent changes in hepatic cell metabolism of Chionodraco hamatus (stripped bars) and Lepidonotothen squamifrons (clear bars) obtained using intermittent-flow respirometry. (a) Total respiration rates, (b) cycloheximide-sensitive respiration rates and (c) fraction of protein synthesis to total respiration. *Rates are significantly different to respective rates at $1{ }^{\circ} \mathrm{C}$. ${ }^{\#}$ Data are significantly different between species at same assay temperature. Values are means $\pm \mathrm{SD}, n=4-5$ (C. hamatus) and $n=5-9$ (L. squamifrons)

expenditure for protein synthesis at $5{ }^{\circ} \mathrm{C}$ (Holm-Sidak test, $p=0.426$; Fig. 2c). 


\section{Discussion}

Long-term warm acclimation did not affect the energy metabolism of primary hepatocytes of the Antarctic eelpout $P$. brachycephalum. Although unexpected, the result agrees with findings at the mitochondrial level. After long-term warm acclimation, hepatic mitochondrial respiration did not differ between non-acclimated $\left(0{ }^{\circ} \mathrm{C}\right.$, control $)$ and warmacclimated $\left(5^{\circ} \mathrm{C}\right) \mathrm{P}$. brachycephalum (Lannig et al. 2005). In light of a significantly lowered HSI but a similar hepatic mitochondrial content (expressed per $\mathrm{g}$ liver mass) in warmcompared to control-acclimated fish, the authors concluded that thermal compensation of hepatic aerobic capacities is achieved by changes in liver size. In agreement with the previous study, warm-acclimated $P$. brachycephalum had a reduced HSI but unchanged cell respiration rates, indicating again that thermal adjustments of hepatic energy metabolism are mainly accomplished at the whole-organ level and less by alterations at the cellular or subcellular level. Similarly, after long-term incubation to different temperatures, $P$. brachycephalum showed a warming-induced reduction in HSI, and whole-animal routine metabolic rates did not differ between acclimation groups (Brodte et al. 2006a; Windisch et al. 2014).

Our findings of temperature-induced changes in cellular energy allocation to protein synthesis corresponded nicely with literature findings at the whole-animal level of $P$. brachycephalum. We measured highest cellular energy expenditure for hepatic protein synthesis at $5{ }^{\circ} \mathrm{C}$, which coincided with highest growth rates of $P$. brachycephalum between 3 and $5{ }^{\circ} \mathrm{C}$ (Brodte et al. 2006a; Windisch et al. 2014). Confirming our first working hypothesis, temperature-dependent cellular energy expenditure for protein synthesis correlated with the inverse U-shaped curve of temperature-dependent growth performance. Temperature-induced changes in cellular energy budget, i.e. cellular energy allocation to protein synthesis are, therefore, suggested to mirror the temperature tolerance of the whole animal with respect to growth performance. In this context, we can interpret the results of the sub-Antarctic grey rockcod L. squamifrons and the high-Antarctic icefish $C$. hamatus. Both species showed significantly elevated cell respiration at $5{ }^{\circ} \mathrm{C}$ compared to $1{ }^{\circ} \mathrm{C}$. Unlike C. hamatus, L. squamifrons also showed an altered energy budget with significantly increased net as well as fractional oxygen demand for protein synthesis at $5{ }^{\circ} \mathrm{C}$. Compared to $P$. brachycephalum, whole-animal physiology and thermal tolerance are less well studied in L. squamifrons and $C$. hamatus. Conclusions, however, can be drawn based on the differences in distribution ranges and prevailing habitat temperatures of the species and, with caution, based on the limited available data on temperature tolerance. Similar to $P$. brachycephalum, $L$. squamifrons inhabits a warmer and wider temperature range than the high-Antarctic $C$. hamatus. Its thermal tolerance seems comparable to that of $P$. brachycephalum as both species have a $\mathrm{CT}_{\max }$ of $\sim 15^{\circ} \mathrm{C}$ (Bilyk and DeVries 2011). Furthermore, despite their polar origin, both species are able to adjust mitochondrial capacities after warm acclimation (Lannig et al. 2005; Strobel et al. 2013). Against this background, the warming-induced rise in cellular energy expenditure for protein synthesis indicates improved cellular energetics in L. squamifrons. Similar to $P$. brachycephalum with highest whole-animal growth at temperatures around $5{ }^{\circ} \mathrm{C}$, the sub-Antarctic $L$. squamifrons will most likely benefit from warmer waters in terms of enhanced growth rates. On the opposite side, we expected that $C$. hamatus, which lives at temperatures $<0{ }^{\circ} \mathrm{C}$ displays highest energy expenditure for protein synthesis at the lower assay temperature, in accordance with its high degree of cold adaptation. Unlike $P$. brachycephalum and $L$. squamifrons, $C$. hamatus showed, however, no temperature-induced changes in cellular energy budget. Irrespective of assay temperature $\left(1^{\circ} \mathrm{C}\right.$ and $\left.5{ }^{\circ} \mathrm{C}\right)$, energy expenditure for protein synthesis varied between 12 and $14 \%$, and values were somewhat lower than those described for the icefish species Chaenocephalus aceratus and Pseudochaenichthys georgianus $\left(17 \%-20 \%\right.$, measured at $5{ }^{\circ} \mathrm{C}$, Lewis et al. 2015). The observed temperature insensitivity may have resulted from the choice of assay temperatures missing the optimal temperature range for $C$. hamatus. This seems conceivable as fractional costs for protein synthesis were in the range of those obtained at suboptimal temperatures for P. brachycephalum. Future studies on the cell metabolism of icefish, with an adjusted experimental protocol (measurements at narrower temperature steps including temperatures below $1{ }^{\circ} \mathrm{C}$ ) are necessary to identify the optimal thermal range for $C$. hamatus. Furthermore, we investigated only one species per ecotype, which somewhat limits our comparative approach, and we would like to emphasize that more work is needed to depict temperature-dependent cellular response along a latitudinal gradient.

The present results indicate that hepatic energy expenditure for protein synthesis correlates with temperaturedependent whole-animal growth performance. It should, however, be noted that not all the energy that is invested in the synthesis of proteins will finally appear as somatic growth. Besides growth, protein synthesis is essential for other functions such as protection (e.g. synthesis of heat shock proteins, HSPs) or replacement of aged and damaged proteins (protein turnover). It is therefore worth to investigate how cellular energy expenditure for protein synthesis is distributed between protein turnover, growth and protection mechanisms at different temperatures and to what extent excess de novo protein synthesis compensates for temperature-induced stress. In this context, it would be also interesting to measure the temperature-dependent allocation to 
protein synthesis in white muscle tissue. The specific growth rate of white muscle is a major contributor to whole-animal growth because almost all the protein synthesized appears as somatic growth (Houlihan et al. 1986, 1988; Peragón et al. 2001). Compared to other tissues, however, white muscle has also the lowest fractional rate of protein synthesis (Houlihan et al. 1986, 1988; Peragón et al. 2001), which adversely affects the signal-to-noise ratio. Investigations of the thermal response of white muscle tissue may therefore require highly sensitive methods, in particular for measurements at low temperatures where metabolic rates are depressed. Even though studies on white muscle might be preferable, Houlihan et al. (1988) could show that increased animal growth rates correlated with higher protein synthesis rates in the liver. Notably, long-term acclimation of $P$. brachycephalum to temperatures above $5{ }^{\circ} \mathrm{C}$ led to changes in hepatic transcript levels such as the induction of genes encoding HSPs, the upregulation of ribosomal transcripts and the activation of lysosomal protein degradation (Windisch et al. 2014). The observed changes indicate that excessive warming increased protein damage and hampered cell division coinciding with reduced growth performance. In $P$. brachycephalum and $C$. hamatus, warming to $10{ }^{\circ} \mathrm{C}$ and $5{ }^{\circ} \mathrm{C}$, respectively, significantly increased total cell respiration but not the respiration that accounted for protein synthesis. Together with the fact that oxygen saturation was always high which excludes possible warming-induced hypoxemia, temperature-dependent changes in cellular energy allocation might be one component to explain temperature-dependent whole-animal growth performance. The warming-induced rise in total cell respiration suggests elevated maintenance costs of idling mitochondria and/or transmembrane ion exchange mechanisms and needs further investigation to unravel the underlying energyconsuming processes. In this respect, Mark et al. (2005) performed a comprehensive study by investigating the thermal response of several metabolic processes: protein synthesis, RNA/DNA synthesis, ion regulation via $\mathrm{Na}^{+} / \mathrm{K}^{+}$-ATPase, and ATP synthesis. The authors investigated hepatocytes of various high- and sub-Antarctic fish species between 0 and $15^{\circ} \mathrm{C}$ but observed only minor evidence for a temperaturedependent shift in ATP-consuming processes (incl. protein synthesis). Likewise, Pannevis and Houlihan (1992) investigated the effect of warming $\left(5{ }^{\circ} \mathrm{C}\right.$ to $\left.20{ }^{\circ} \mathrm{C}\right)$ on hepatic respiration and absolute protein synthesis rates in Oncorhynchus mykiss. They observed a thermal optimum of cellular protein synthesis rates at intermediate temperatures $\left(14{ }^{\circ} \mathrm{C}\right.$ $-18{ }^{\circ} \mathrm{C}$, indicated by increased phenylalanine incorporation rates), however, without clear evidence for a temperature-induced change in the oxygen consumption allocated to protein synthesis. This contrasts with present observations of a significant temperature effect on cellular energy allocation to protein synthesis in $P$. brachycephalum and $L$. squamifrons. The present cell study on P. brachycephalum included a comparison of experimental setups (intermittentflow vs. closed system respirometry). In light of the fact that the measurements with the intermittent-flow system but not the ones with the closed system revealed a significant temperature impact on the hepatic energy budget, we suggest that the conflicting results may be due to the use of closed system respirometry in the previous studies. Based on our results, we consider the intermittent-flow system more sensitive and advantageous to investigate cellular response to changing temperatures. It avoids accumulation of $\mathrm{CO}_{2}$, metabolic wastes and exhaustion of substrates and allows measurements on the same cell cohort, resulting in reproducible and less variable results. In addition to other potential confounding factors such as media composition (Wieser and Krumschnabel 2001; Stapp et al. 2015), which should be adjusted to mimic the best possible species-specific in vivo conditions, the use of different experimental setups may bias measurements of cellular response to warming and needs to be considered in future studies.

\section{Conclusion}

The study demonstrates the potential of cellular studies to identify thermal tolerance ranges in marine ectotherms. Present investigations on P. brachycephalum, where wholeanimal physiology and thermal tolerance are very well studied, revealed a clear link between temperature-dependent whole-animal growth and cellular energy expenditure for protein synthesis. Furthermore, in line with the species' geographical distributions and natural temperature regimes, temperature-induced changes in cellular energy expenditure for protein synthesis differed between $L$. squamifrons and C. hamatus. These differences are suggested to parallel species' temperature tolerance and their degree of cold adaptation. Despite its preliminary character, the present study implies that cell studies could possibly replace time-consuming studies of whole-animal growth in thermal biology. This is of particular interest for polar fish where alive and healthy fish are often limited or hard to handle in captivity. Moreover, compared to the closed system the intermittentflow respirometry seems to be a more sensitive method, which gives some advantages to detect temperature-induced changes in cellular energy budget of marine ectotherms.

Acknowledgements We thank the crew of RV Polarstern for technical support in animal capture and maintenance as well as the crew of our institutional aquarium facility, in particular F. Veliz Moraleda, for taking care of animals and water quality. We greatly acknowledge T. Hirse for experimental help on board, K. Mintenbeck for help in ecological background, C. Bock and H.O. Pörtner for insightful discussions and I. Sokolova and A. Bleyer for helpful critique on the manuscript. This work was supported by the research programme "Polar regions And 
Coasts in the changing Earth System" (PACES) of the Alfred Wegener Institute.

Author contributions All authors made substantial contributions to the presented work. The conception of the study was designed by GL. Material preparation and data collection were performed by AT, SH and LSS. Data analysis were performed by SH and LSS with support of GL. GL wrote the manuscript, which was revised by all authors. All authors read and approved the final manuscript.

Funding Open Access funding enabled and organized by Projekt DEAL.

Data availability The datasets generated and analysed during the current study are available in PANGAEA (after publication).

\section{Compliance with ethical standards}

Conflict of interest The authors declare that they have no conflict of interest.

Ethical approval We declare that sampling of fish species and presented experiments comply with current legislation. The studies have been approved by the appropriate national research ethics committee and permits were released by the Senator for Healthcare, Bahnhofsplatz 29, 28195 Bremen on January 15, 2008 (Az.: 522-27-11/02-00 (93), permit valid until January 14, 2011) and February 21, 2013 (SYNKLIFisch Az.: 522-27-11/02-00 (113), permit valid until February 21, 2018) and by the German Environment Agency (UBA, permission number 13.5-94003-3/222 (for 2009) and /253 (for 2011).

Open Access This article is licensed under a Creative Commons Attribution 4.0 International License, which permits use, sharing, adaptation, distribution and reproduction in any medium or format, as long as you give appropriate credit to the original author(s) and the source, provide a link to the Creative Commons licence, and indicate if changes were made. The images or other third party material in this article are included in the article's Creative Commons licence, unless indicated otherwise in a credit line to the material. If material is not included in the article's Creative Commons licence and your intended use is not permitted by statutory regulation or exceeds the permitted use, you will need to obtain permission directly from the copyright holder. To view a copy of this licence, visit http://creativecommons.org/licenses/by/4.0/.

\section{References}

Anderson ME (1989) Review of the eelpout genus Pachycara Zugmayer 1911 (Teleostei:Perciformes) with descriptions of six new species. Proc Calif Acad Sci 46:221-242

Atkinson D (1977) Cellular metabolism and its regulation. Academic Press, New York

Beers JM, Jayasundara N (2015) Antarctic notothenioid fish: what are the future consequences of "losses" and "gains" acquired during long-term evolution at cold and stable temperatures? J Exp Biol 218:1834-1845

Beers JM, Sidell BD (2011) Thermal tolerance of Antarctic notothenioid fishes correlates with level of circulating hemoglobin. Physiol Biochem Zool 84:353-362

Bilyk KT, DeVries AL (2011) Heat tolerance and its plasticity in Antarctic fishes. Comp Biochem Physiol A 158:382-390
Brodte E, Knust R, Pörtner HO (2006a) Temperature-dependent energy allocation to growth in Antarctic and boreal eelpout (Zoarcidae). Polar Biol 30:95-107

Brodte E, Knust R, Pörtner HO, Arntz W (2006b) Biology of the Antarctic eelpout Pachycara brachycephalum. Deep-Sea Res II 53:1131-1140

Boutilier RG (2001) Mechanisms of cell survival in hypoxia and hypothermia. J Exp Biol 204:3171-3181

Cherkasov AS, Biswas PK, Ridings DM, Ringwood AH, Sokolova IM (2006) Effects of acclimation temperature and cadmium exposure on cellular energy budgets in the marine mollusk Crassostrea virginica: linking cellular and mitochondrial responses. J Exp Biol 209:1274-1284

Clarke A, Johnston IA (1996) Evolution and adaptive radiation of Antarctic fishes. Trends Ecol Evol 2:212-218

Convey P, Peck LS (2019) Antarctic environmental change and biological responses. Sci Adv 11:eaaz0888

diPrisco G (2000) Life style and biochemical adaptation in Antarctic fishes. J Mar Syst 27:253-265

Fly EK, Hilbish TJ (2013) Physiological energetics and biogeographic range limits of three congeneric mussel species. Oecologia 172:35-46

Fonds M, Jaworski A, Iedema A, Puyl PVD (1989) Metabolism, food consumption, growth and food conversion of shorthorn sculpin (Myoxocephalus scorpius) and eelpout (Zoarces viviparus). Document G:31. International Council for Exploration of the Sea, Copenhagen

Fonds M, Cronie R, Vethaak A, Van der Puyl P (1992) Metabolism, food consumption and growth of plaice (Pleuronectes platessa) and flounder (Platichthys flesus) in relation to fish size and temperature. Neth J Sea Res 29:127-143

Franklin CE, Davison W, Seebacher F (2007) Antarctic fish can compensate for rising temperatures: thermal acclimation of cardiac performance in Pagothenia borchgrevinki. J Exp Biol 210:3068-3074

Garofalo F, Pellegrino D, Amelio D, Tota B (2009) The Antarctic hemoglobinless icefish, fifty five years later: A unique cardiocirculatory interplay of disaptation and phenotypic plasticity. Com Biochem Physiol A 154:10-28

Gon O, Heemstra PC (1990) Fishes of the Southern Ocean. J.L.B Smith Institute of Ichthyology, Grahamstown

Gräns A, Jutfelt F, Sandblom E, Jönsson E, Wiklander K, Seth H, Olsson C, Dupont S, Ortega-Martinez O, Einarsdottir I, Björnsson BT, Sundell K, Axelsson M (2014) Aerobic scope fails to explain the detrimental effects on growth resulting from warming and elevated $\mathrm{CO}_{2}$ in Atlantic halibut. J Exp Biol 217:711-717

Guderley H (1990) Functional significance of metabolic responses to thermal acclimation in fish muscle. Am J Physiol 259:R245-R252

Houlihan DF (1991) Protein turnover in ectotherms and its relationships to energetics. In: Gilles R (ed) Advances in comparative and environmental physiology, vol 7. Springer, Heidelberg, pp 1-43

Houlihan DF, McMillan DN, Laurent P (1986) Growth rates, protein synthesis, and protein degradation rates in rainbow trout: effects of body size. Physiol Zool 59:482-493

Houlihan DF, Hall SJ, Gray C, Noble BS (1988) Growth rates and protein turnover in Atlantic cod (Gadus morhua). Can J Fish Aquat Sci 43:951-964

Iwami T, Kock KH (1990) Channichthyidae. In: Gon O, Heemstra PC (eds) Fishes of the Southern Ocean. J.L.B Smith Institute of Ichthyology, Grahamstown, pp 381-389

Johnston IA (2003) Muscle metabolism and growth in Antarctic fishes (suborder Notothenioidei): evolution in a cold environment. Comp Biochem Physiol B 136:701-713

Johnston IA, Dunn J (1987) Temperature acclimation and metabolism in ectotherms with particular reference to teleost fish. Symp Soc Exp Biol 41:67-93 
Kock KH (2005a) Antarctic icefishes (Channichthyidae): a unique family of fishes. A review, Part I. Polar Biol 28:862-895

Kock KH (2005b) Antarctic icefishes (Channichthyidae): a unique family of fishes. A review, Part II. Polar Biol 28:897-909

Langenbuch M, Pörtner HO (2003) Energy budget of hepatocytes from Antarctic fish (Pachycara brachycephalum and Lepidonotothen kempi) as a function of ambient $\mathrm{CO}_{2}: \mathrm{pH}$-dependent limitations of cellular protein biosynthesis? J Exp Biol 206:3895-3903

Lannig G, Eckerle L, Serendero I, Sartoris FJ, Fischer T, Knust R, Johansen T, Pörtner HO (2003) Temperature adaptation in eurythermal cod (Gadus morhua): a comparison of mitochondrial enzyme capacities in boreal and Arctic populations. Mar Biol 142:589-599

Lannig G, Storch D, Pörtner HO (2005) Aerobic mitochondrial capacities in Antarctic and temperate eelpout (Zoarcidae) subjected to warm versus cold acclimation. Polar Biol 28:575-584

Lannig G, Eilers S, Pörtner HO, Sokolova IM, Bock C (2010) Impact of ocean acidification on energy metabolism of oyster, Crassostrea gigas — changes in metabolic pathways and thermal response. Marine Drugs 8:2318-2339

Lewis JM, Grove TJ, O'Brien KM (2015) Energetic costs of protein synthesis do not differ between red- and white-blooded Antarctic notothenioid fishes. Comp Biochem Physiol A 187:177-183

Mark FC, Bock C, Pörtner HO (2002) Oxygen limited thermal tolerance in Antarctic fish investigated by magnetic resonance imaging (MRI) and spectroscopy $\left({ }^{31} \mathrm{P}-\mathrm{MRS}\right)$. Am J Physiol 283:R1254-R1262

Mark FC, Hirse T, Pörtner HO (2005) Thermal sensitivity of cellular energy budgets in some Antarctic fish hepatocytes. Polar Biol 28:805-814

Mintenbeck K, Barrera-Oro ER, Brey T, Jacob U, Knust R, Mark FC, Moreira E, Strobel A, Arntz WE (2012) Impact of climate change on fishes in complex Antarctic Ecosystems. Adv Ecol Res 46:351-426

Mommsen TP, Moon T, Walsh PJ (1994) Hepatocytes: isolation, maintenance and utilization. In: Hochachka P, Mommsen TP (eds) Biochemistry and molecular biology of fishes. Elsevier, Amsterdam, pp 355-373

Mueller IA, Devor DP, Grim JM, Beers JM, Crockett EL, O’Brien KM (2012) Exposure to critical thermal maxima increases oxidative stress in hearts of white but not red-blooded Antarctic notothenioid fishes. J Exp Biol 215:3655-3664

Pakhomov EA, Bushula T, Kaehler S, Watkins BP, Leslie RW (2006) Structure and distribution of the slope fish community in the vicinity of the sub-Antarctic Prince Edward Archipelago. J Fish Biol 68:1834-1866

Pannevis MC, Houlihan DF (1992) The energetic cost of protein synthesis in isolated hepatocytes of rainbow trout (Oncorhynchus mykiss). J Comp Physiol B 162:393-400

Peck LS (2016) A Cold Limit to Adaptation in the Sea. Trends Ecol Evol 31:13-26

Peck LS (2018) Antarctic marine biodiversity: adaptations, environments and responses to change. In: Hawkins SJ, Evans AJ, Dale AC, Firth LB, Smith IP (eds) Oceanography and marine biology: an annual review, vol 56. CRC Press, Boca Raton, pp 1-133

Peck LS, Morley SA, Richard J, Clark MS (2014) Acclimation and thermal tolerance in Antarctic marine ectotherms. J Exp Biol 217:16-22

Peragón J, Barrosco JB, García-Salguero L, de la Higuera M, Lupiánez JA (2001) Growth, protein-turnover rates and nucleic-acid concentrations in the white muscle of rainbow trout during development. IJBCB 33:1227-1238

Pörtner HO (2006) Climate-dependent evolution of Antarctic ectotherms: an integrative analysis. Deep Sea Res II 53:1071-1104

Pörtner HO, Lannig G (2009) Oxygen and capacity limited thermal tolerance. In Richards JG, FarrellAP, Brauner CJ (eds) Fish physiology: hypoxia. Academic Press/Elsevier, New York/San Diego, ISBN: 978-0-12-374632-0, pp 143-191

Pörtner HO, Peck MA (2010) Climate change effects on fishes and fisheries: towards a cause-and-effect understanding. J Fish Biol 77:1745-1779

Pörtner HO, Berdal B, Blust R, Brix O, Colosimo A, de Wachter B, Giuliani A, Johansen T, Fischer T, Knust R, Lannig G, Naevdal G, Nedenes A, Nyhammer G, Sartoris FJ, Serendero I, Sirabella P, Thorkildsen S, Zakhartsev M (2001) Climate induced temperature effects on growth performance, fecundity and recruitment in marine fish: developing a hypothesis for cause and effect relationships in Atlantic cod (Gadus morhua) and common eelpout (Zoarces viviparus). Cont Shelf Res 21:1975-1997

Pörtner HO, Bock C, Knust R, Lannig G, Lucassen M, Mark FC, Sartoris FJ (2008) Cod and climate in a latitudinal cline: physiological analyses of climate effects in marine fishes. Clim Res 37:253-270

Rolfe DFS, Brown GC (1997) Cellular energy utilization and molecular origin of standard metabolic rate in mammals. Physiol Rev 77:731-758

Ruud JT (1954) Vertebrates without erythrocytes and blood pigment. Nature 4410:848-850

Sandersfeld T, Davison W, Lamare MD, Knust R, Richter C (2015) Elevated temperature causes metabolic trade-offs at the wholeorganism level in the Antarctic fish Trematomus bernacchii. J Exp Biol 218:2373-2381

Schulte PM, Healy TM, Fangue NA (2011) Thermal performance curves, phenotypic plasticity, and the time scales of temperature exposure. Integr Comp Biol 51:691-702

Seebacher F, Davison W, Lowe CJ, Franklin CE (2005) A falsification of the thermal specialization paradigm: compensation for elevated temperatures in Antarctic fishes. Biol Lett 1:151-154

Sidell BD, O'Brien KM (2006) When bad things happen to good fish: the loss of hemoglobin and myoglobin expression in Antarctic icefishes. J Exp Biol 209:1791-1802

Stapp LS, Kreiss CM, Pörtner HO, Lannig G (2015) Differential impacts of elevated $\mathrm{CO}_{2}$ and acidosis on the energy budget of gill and liver cells from Atlantic cod, Gadus morhua. Com Biochem Physiol A 187:160-167

Storch D, Lannig G, Pörtner HO (2005) Temperature dependent protein synthesis capacities in Antarctic and temperate (North Sea) fish (Zoarcidae). J Exp Biol 208:2409-2420

Strobel A, Graeve M, Poertner HO, Mark FC (2013) Mitochondrial acclimation capacities to ocean warming and acidification are limited in the Antarctic notothenioid fish, Notothenia rossii and Lepidonotothen squamifrons. PLoS ONE 8(7):e68865

Thedinga E, Ullrich A, Drechsler S, Niendorf R, Kob A, Runge D, Keuer A, Freund I, Lehmann M, Ehret R (2007) In vitro System for the prediction of hepatotoxic effects in primary hepatocytes. Altex 24:22-34

van Dijk PLM, Tesch C, Hardewig I, Pörtner HO (1999) Physiological disturbances at critically high temperatures: a comparison between stenothermal Antarctic and eurythermal temperate eelpouts (Zoarcidae). J Exp Biol 202:3611-3621

Verde C, Parisi E, di Prisco G (2006) The evolution of thermal adaptation in polar fish. Gene 385:137-145

Ward P (1989) The distribution of zooplankton in an Antarctic fjord at South Georgia during summer and winter. Antarct Sci 1:141-150

Wieser W, Krumschnabel G (2001) Hierarchies of ATP-consuming processes: direct compared with indirect measurements, and comparative aspects. Biochem J 355:389-395

Windisch HS, Frickenhaus S, John U, Knust R, Pörtner HO, Lucassen M (2014) Stress response or beneficial temperature acclimation: transcriptomic signatures in Antarctic fish (Pachycara brachycephalum). Mol Ecol 23:3469-3482

Publisher's Note Springer Nature remains neutral with regard to jurisdictional claims in published maps and institutional affiliations. 